\title{
Geometra papilionaria (Linnaeus, 1758) (Lepidoptera: Geometridae): a new species for the fauna of Greece
}

\author{
B. TÓTH
}

Balázs Tóth, Lepidoptera Collection, Department of Zoology, Hungarian Natural History Museum, Baross utca 13, H-1088, Budapest, Hungary.Email: toth.balazs@nhmus.hu

\begin{abstract}
The first record of Geometra papilionaria L. from Greece is provided, extending the known area of the species in the Balkan Peninsula and raising the Geometrinae fauna of Greece to 18 species. A brief characterisation of the collecting site is also given. The voucher specimen is deposited in the Hungarian Natural History Museum, Budapest. With two figures.
\end{abstract}

Keywords. Geometrinae, new record, macchia shrubland, Balkan Peninsula, Hungarian Natural History Museum

\section{INTRODUCTION}

$\mathrm{T}$ he emerald moth Geometra papilionaria, unlike its congeners, has a vast range in the cool temperate zone of the Palaearctic Region from its Pacific to the Atlantic coasts. In Europe, this species is distributed from the northernmost point of the Scandinavian Peninsula to the northern latitude of $39^{\circ}$ in the Iberian and Italian Peninsulae, and to Southeastern Macedonia in the Balkan Peninsula (Hausmann 2001, Huemer et al. 2011). It can easily be distinguished from all other European geometrid moths by its large size and deep green ground-colour. The species primarily inhabits woodlands with birch or alder.

Exploration of the fauna of the Balkan Peninsula has a long history in Hungary. As early as the first half of the $19^{\text {th }}$ century several Lepidoptera species were described by Hungarian scientists e.g. Plebejus sephirus, Behounekia freyeri or Phragmatobia placida (Frivaldszky 1835) and new faunistic data have been published in recent years as well (Tóth et al. 2013). Last but not least, it must be mentioned that the greatest monographer of the Lepidopteran fauna of Greece hitherto known is the late László Gozmány (1921-2006), former curator of the Hungarian Natural History Museum (see Gozmány 2012).
The aim of this publication is to provide the first record of G. papilionaria from Greece, thus continue the tradition of investigation the fauna of the Balkans.

\section{MATERIAL AND METHODS}

One male was collected at light by Hungarian coleopterists during an expedition to Greece. The specimen is pinned and mounted, deposited in the Hungarian Natural History Museum (HNHM), Budapest.

Material examined. $1 \delta^{\top}$ : "GREECE, Makedonia, pref. Florina, $5 \mathrm{~km}$ E Kella macchia, 40 $47^{\prime}$ $53.23^{\prime \prime} \mathrm{N}, 21^{\circ} 46^{\prime} 07.95^{\prime \prime} \mathrm{E}, 635 \mathrm{~m}$, at light, 26.VI. 2012, No. 7, leg. A. Kotán, A. Márkus, P. Nemes \& T. Németh".

\section{RESULTS AND DISCUSSION}

The specimen (Fig. 1) was found during sorting out unidentified accession material in the HNHM. The wingspan and the date of collecting of the specimen fall within the mean range of these two variables. The shape and pattern of wings are also characteristic for this species (Hausmann 2001), hence genital dissection was considered to be unnecessary. 


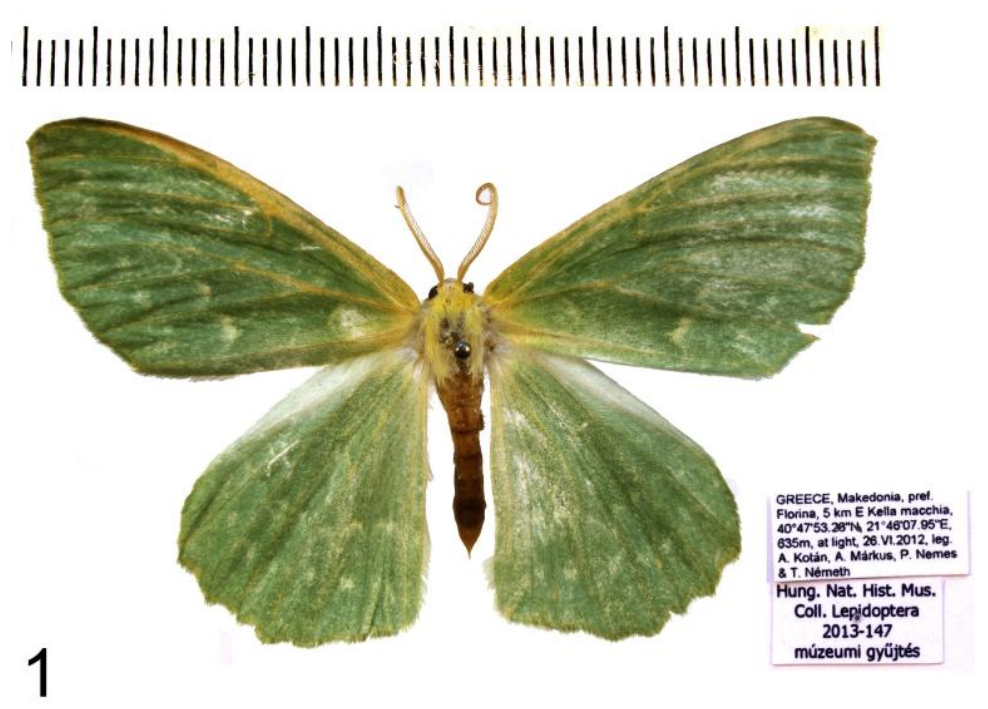

Figure 1. Image of Geometra papilionaria L. from Greece.

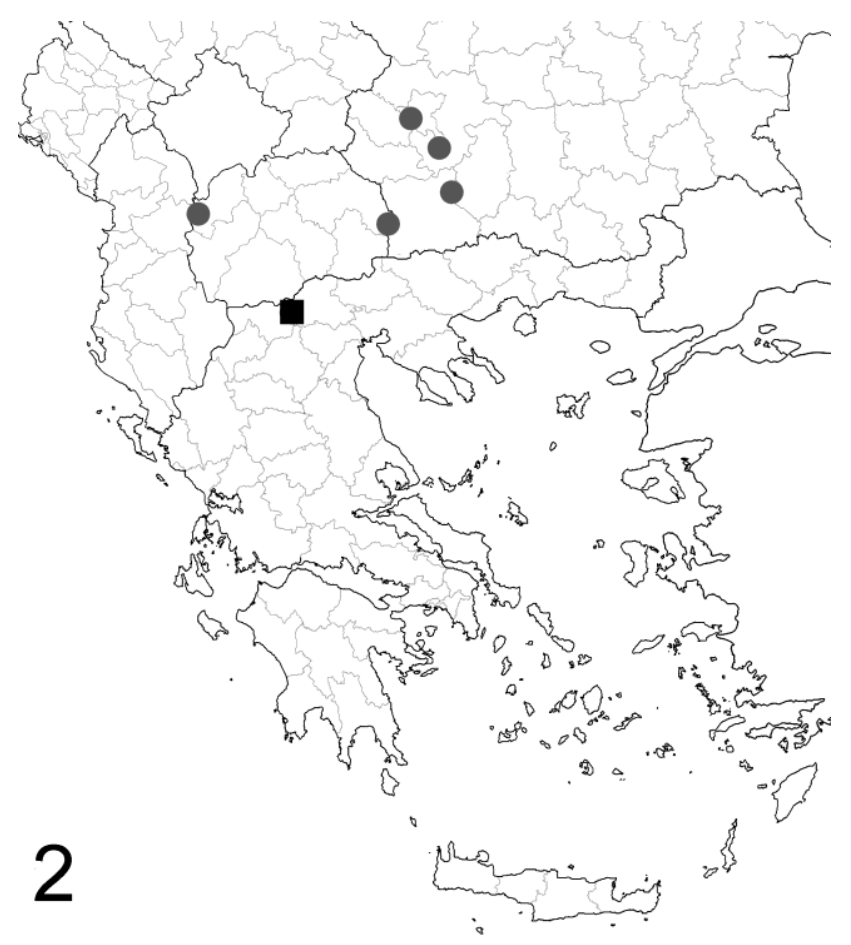

Figure 2. Distribution of G. papilionaria in the Balkan Peninsula; grey dots are from Hausmann (2001) and Huemer et al. (2011), the new record from Greece is marked by black square.

The collecting site is situated at the southern foothills of the Kaimaktsalan Mountains, ca. 15 $\mathrm{km}$ south of the Greek-Macedonian border, close to Vegoritida Lake (Fig. 2). The habitat type is
Mediterranean macchia shrubland, which is highly atypical for this species. The closest suitable habitats, i.e. montane beech forests or cool stream-valleys with alder, can be found several 
kilometres away, therefore the specimen was likely showing dispersal behaviour. This phenomenon could rarely appear according to faunistic data of the HNHM collection.

As this species regularly comes to light, the method of collection is ordinary.

This record represents the southernmost locality of G. papilionaria in the Balkan Peninsula, raising the number of Geometrinae species occurring in Greece to 18 .

\section{Checklist of the subfamily Geometrinae in Greece. Taxa are listed in systematic order according to Hausmann (2001):}

Aplasta ononaria (Fuessly, 1783)

Pseudoterpna pruinata (Hufnagel, 1767)

Pseudoterpna coronillaria cinerascens (Zeller, 1847)

Geometra papilionaria (Linnaeus, 1758); new record

Comibaena bajularia ([Denis \& Schiffermüller], 1775)

Proteuchloris neriaria (Herrich-Schäffer, 1852)

Thetidia smaragdaria (Fabricius, 1787)

Hemistola chrysoprasaria (Esper, 1795)

Xenochlorodes olympiaria (Herrich-Schäffer, 1852)

Eucrostes indigenata (de Villers, 1789)

Jodis lactearia (Linnaeus, 1758)

Thalera fimbrialis (Scopoli, 1763)

Hemithea aestivaria (Hübner, 1789)

Chlorissa viridata (Linnaeus, 1758)

Chlorissa cloraria (Hübner, 1813)

Phaiogramma etruscaria (Zeller, 1849)

Phaiogramma faustinata (Millière, 1868)

Microloxia herbaria (Hübner, 1813)
Acknowledgements - I am indebted to Dr Zsolt Bálint for the critical review of the manuscript. I am grateful to $\mathrm{Mr}$ Gergely Katona for the help of taking photographs of the $G$. papilionaria specimen and to Mr Tamás Németh, one of the collectors of the specimen, for valuable information on the collecting site. All of them are staff members of the HNHM.

\section{REFERENCES}

FRIVALDSZKY, I. (1835): Közlések a 'Balkány' vidékén tett természettudományi utazásról [Contributions on the scientific expedition to the Balkan region - in Hungarian]. A Magyar Tudós Társaság Évkönyvei, 2: 235-276. Magyar Királyi Egyetem, Buda.

GoZMÁNY, L. (2012): The Lepidoptera of Greece and Cyprus, volume 1. Hellenic Zoological Society, Athens, pp. 414.

HAusmann, A. (2001): Introduction. Archiearinae, Orthostixinae, Desmobathrinae, Alsophilinae, Geometrinae. In. Hausmann, A. (Ed.) The geometrid moths of Europe 1: 1-282.

Huemer, P., Krpač, V., Plössl, B. \& Tarmann, G. (2011): Contribution to the fauna of Lepidoptera of the Mavrovo National Park (Republic of Macedonia). Acta Entomologica Slovenica, 19 (2): 169186.

Tóth, B., BАBICS, J., \& BeNEDEK, B. (2013): Contributions to knowledge of the geometrid fauna of Bulgaria and Greece, with four species new for the Greek fauna (Lepidoptera: Geometridae). Esperiana, 18: 221-224, plate 12. 